\title{
Knowledge and acceptability of HPV vaccine among HPV-vaccinated and unvaccinated adolescents at Western Amazon
}

\author{
(D) Maria Sulenir Ferreira de Oliveira ${ }^{1}$ \\ (iD) Isabel Cristina Esposito Sorpreso ${ }^{2}$ \\ (iD) Lea Tami Suzuki Zuchelo² \\ (iD) Adna Thaysa Marcial da Silva ${ }^{1,2}$ \\ (iD) Jéssica de Menezes Gomes ${ }^{1,2}$ \\ Bhárbara Karolline Rodrigues Silva ${ }^{1,3}$ \\ (iD) Luiz Carlos de Abreu ${ }^{1,4}$ \\ (iD) Rubens Wajnsztejn ${ }^{1}$
}

\begin{abstract}
1. Laboratório de Delineamento de Estudos e Escrita Científica da Faculdade de Medicina do ABC, Santo André, SP, Brasil. 2. Disciplina de Ginecologia, Departamento de Obstetríicia e Ginecologia, Faculdade de Medicina, Universidade de São Paulo, São Paulo, Brasil.

3. Laboratório de Epidemiologia e Análise de Dados, Faculdade de Medicina do ABC (FMABC), Santo André, SP, Brasil. 4. Faculdade de Ciências da Santa Casa de Misericórdia de Vitória (Emescam), Vitória, ES, Brasil.
\end{abstract}

http://dx.doi.org/10.1590/1806-9282.66.8.1062

\section{SUMMARY}

PURPOSE: To analyze the level of knowledge about and the acceptability of the HPV vaccine among vaccinated and unvaccinated adolescents in the Western Amazon.

METHODS: A cross-sectional study on adolescents aged 10 to 19 years. The instrument used to collect data contains demographic and socioeconomic information and 27 questions that assess the knowledge and acceptability of the HPV vaccine. To compare the prevalence of vaccinated adolescents with the correct answers to questions about HPV and acceptability and vaccination, the robust variance Poisson regression model was used in the Stata 13.0 software.

FINDINGS: A total of 190 adolescents participated in the study, $60.5 \%$ in the age group of vaccination recommended by the Brazilian government, among them, $53.9 \%$ reported not having been vaccinated ( $p<0.001)$. A total of $150(78.9 \%)$ adolescents correctly recognized HPV as a virus; 121 (63.7\%) recognized HPV as a cause of cervical cancer. Participants who know HPV is a causative factor for cervical cancer are 1.94 times more likely to have been vaccinated than those who do not. Among the interviewees, the main sources of knowledge about the vaccine were schools (51.6\%) and health professionals (22.6\%).

CONCLUSION: Unvaccinated adolescents have knowledge gaps about HPV and its vaccine when compared to those vaccinated. Our results emphasize the need for effective campaigns to deliver adequate information about HPV and its vaccine to adolescents, their parents, and health professionals.

KEYWORDS: Perception. Vaccines. Papillomaviridae. Adolescent.

\section{INTRODUCTION}

The human papillomavirus (HPV) infection is considered a frequent viral infection among sexually active individuals. In adolescence, multi-partner behavior without the use of condoms may increase the risk of infection ${ }^{1,2}$.

In 2014, the Ministry of Health introduced in the
National Immunization Program (NIP) the quadrivalent human papillomavirus vaccine for girls aged 9 to 14 and, since 2017 , for boys aged 11 to 14 . The inclusion of male adolescents strengthens health actions targeted at this group ${ }^{2}$. 
The World Health Organization (WHO) considers vaccine coverage adequate when there are $80 \%$ inoculations in the priority population at the second dose $^{2}$. In Brasil and in the Federative Unit of Acre there were $64.48 \%$ and $49.84 \%$ of inoculations in the second dose, respectively ${ }^{3}$. In Acre in 2017, 17.02\% of the female adolescent population and $26.75 \%$ of males were vaccinated for $\mathrm{HPV}^{3}$.

Adolescent's parents present a barrier due to myths that the vaccine is applied against sexual initiation and regarding its safe ${ }^{\text {ty }}$. Sousa et al..$^{5}$ demonstrated a low level of knowledge about the vaccine safety and efficacy among adolescents.

The population for vaccination is in a period considered ideal for primary prevention because it has safe and effective immunological results to reduce the incidence of HPV-related diseases ${ }^{2}$. Sorpreso and Kelly ${ }^{6}$ argue that encouraging information, counseling, and continuing education is an important way to increase the acceptability of the vaccine and ensure that new cases of cervical cancer are reduced in the future.

Elucidating the panorama of the adolescent population and target of the HPV vaccine in the Western Amazon is important to women's and public health because of the low HPV vaccine coverage, low socioeconomic income, high prevalence of HPV infections, as well as its repercussions, such as cervical cancer. Thus, the objective of this study is to analyze the level of knowledge about and acceptability of the HPV vaccine among vaccinated and unvaccinated adolescents in the Western Amazon.

\section{METHODS}

\section{Study design}

This is a cross-sectional study presented according to STROBE guidelines ${ }^{7}$ performed in the municipality of Cruzeiro do Sul, in the state of Acre, between May and August 2017.

The research project was approved by the Research Ethics Committee of the União Educacional do Norte - UNINORTE (2.158.359) and authorized by the Municipal Health Department of Cruzeiro do Sul (AC).

\section{Setting}

The study was conducted in a Basic Health Unit (BHU) located in Cruzeiro do Sul that provides health services to low- and middle-income families. The health unit has a multi-professional approach, with doctors, nurses, nursing technicians, and community health agents, all of whom were trained to apply the instrument for data collection.

All adolescents and their legal guardians/parents were informed about the voluntary participation in the research and read the informed consent form. In addition, for adolescents under 14 years of age, we required parental consent and assent form. After signing the informed consent form, the adolescents were interviewed.

The interviews were conducted individually with the adolescents, away from their parents, before the adolescent's medical consultation and during the activities of the group of adolescents, without prejudice to their demands.

\section{Participants}

The sample was composed of 190 adolescents aged 10 to 19 years 11 months and 29 days according to the stratification of the World Health Organization ${ }^{8}$.

Inclusion criteria: adolescents of both sexes, attending the reference BHU UBS. The criteria for non-inclusion were: participants who did not respond to all domains of the questionnaires, adolescent or legal guardian refusal, and impossibility to contact the adolescent (Figure 1).

- insert Figure 1 here-

The adolescents were informed on HPV, repercussions of the vaccine by HPV, and vaccine for HPV after the interview. The adolescents had their medical care preserved without any prejudice to the treatment or follow-up in the basic health unit. Still, the confidentiality of the responses was maintained and any uncomfortable situations were avoided.

\section{VARIABLES AND DATA SOURCE \\ Characterization of the sample}

The socioeconomic and demographic characteristics were obtained through a socioeconomic and demographic identification form ${ }^{5}$. The form consisted of the following variables: gender, age, partner, children, schooling, family income, and paid work.

Knowledge and Acceptability of HPV Vaccine

The collection instrument for assessing the knowledge about and acceptability of the HPV vaccine was adapted from a validated instrument with a sample of adolescents, parents or guardians, and health professionals ${ }^{5}$. We used 27 questions addressing the knowledge about HPV, the vaccine, barriers to vaccination, 
vaccine acceptability, and personal history related to HPV infection. Each question had three possible answers: "Yes," "No," and "Not sure".

\section{Data sources and measurement}

In order to score the answers, the value (0) was attributed to non-correct answers and the "Not sure" option, and (1) to correct answers in each question. The instrument was adapted from the original since these are specific questions for health professionals ${ }^{5}$.

The questionnaire was tested on similar populations in a previous study ${ }^{5}$. To measure the internal consistency of the instrument, the Cronbach's alpha equation was used, obtaining an alpha $(\alpha)$ value of 0.61 , considered a substantial value .

\section{Bias}

To minimize the selection bias, a validated collection instrument was used and applied in a previous study on adolescents. The responses of the adolescents without intervention during the collection and standardization of the collection by an interviewer previously trained were considered. The registration of the data was standardized in an Excel worksheet and the analysis carried out by two researchers.

\section{Statistical methods}

The study was performed with a non-probabilistic sample and for convenience. Considering a power of $80 \%$, a significance level of $5 \%$, and $64 \%$ of vaccinated individuals based on the proportion of vaccination by NIP-Acre, 201727, the minimum number of interviewees necessary was 105.

The data were tabulated in a Microsoft Excel spreadsheet and analyzed by the Statistics Data Analysis software for Windows ${ }^{\circledR}$ (Stata ${ }^{\circledR}$, StataCorp, LLC, 13.0, College Station, TX, USA).

The homogeneity test among the vaccinated and non-vaccinated adolescents, in relation to the socioeconomic variables, was performed by the chi-square test.

For the prevalence of vaccinated adolescents and correct answers, the Poisson regression model with robust variance was used, with a Prevalence Ratio (PR) and Confidence Intervals of 95\% (95\% CI). All analyses were two-tailed, and $\mathrm{p}<0.05$ were considered statistically significant.

The proportion and respective 95\% confidence intervals of the correct answers were used to describe the proportion of correct answers for each question. Information not answered by the participants were considered missing, thus were not considered and not analyzed.

\section{RESULTS}

We interviewed 190 adolescents living in Cruzeiro do Sul-AC, Northern region of Brasil, with a mean age of 14.1 years ( $\mathrm{SD} \pm 2.80$ years), of which 115 (60.5\%) were in the age group for HPV vaccination recommended by the Health Immunization Program, 98 (51.6\%) were female and $92(48.4 \%)$ were males. A total of $179(94.2 \%)$ adolescents reported having no partner, 24 (12.6\%) had one child or more, 29 (15.3\%) had paid work, and 127 (66.8\%) reported lower income than two minimum wages, as seen in Table 1 .

TABLE 1. SOCIOECONOMIC CHARACTERISTICS OF ADOLESCENTS ACCORDING TO THE ACCOMPLISHMENT OF VACCINATION AGAINST HPV OF ADOLESCENTS OF THE WESTERN AMAZON, 2017.

\begin{tabular}{|c|c|c|c|c|}
\hline \multirow[t]{2}{*}{ Variable } & \multirow{2}{*}{$\begin{array}{l}\text { Total } \\
\text { popula- } \\
\text { tion } \\
\mathrm{n}(\%)\end{array}$} & \multicolumn{2}{|c|}{$\begin{array}{l}\text { Vaccinated against } \\
\text { HPV }\end{array}$} & \multirow[t]{2}{*}{$\mathrm{p}^{*}$} \\
\hline & & $\begin{array}{l}\text { NOT } \\
n(\%)\end{array}$ & $\begin{array}{l}\text { YES } \\
n(\%)\end{array}$ & \\
\hline \multicolumn{5}{|l|}{ Target Population ${ }^{\star \star}$} \\
\hline Not & 75 (39.5) & $62(82.7)$ & $13(17.3)$ & \multirow[t]{2}{*}{$<0.001$} \\
\hline Yes & $115(60.5)$ & $62(53.9)$ & $53(46.1)$ & \\
\hline \multicolumn{5}{|l|}{ Sex } \\
\hline Female & $98(51.6)$ & $45(45.9)$ & $53(54.1)$ & \multirow[t]{2}{*}{$<0.001$} \\
\hline Male & $92(48.4)$ & 79 (85.9) & $13(14.1)$ & \\
\hline \multicolumn{5}{|l|}{ Partner } \\
\hline Not & $179(94.2)$ & $115(64.2)$ & $64(35.7)$ & \multirow[t]{2}{*}{0.235} \\
\hline Yes & $11(5.8)$ & $9(81.8)$ & $2(18.2)$ & \\
\hline \multicolumn{5}{|l|}{ Work } \\
\hline Not & $161(84.5)$ & $102(63.4)$ & $59(36.6)$ & \multirow[t]{2}{*}{0.193} \\
\hline Yes & $29(15.3)$ & $22(75.9)$ & $7(24.1)$ & \\
\hline \multicolumn{5}{|l|}{ Have children } \\
\hline Not & $166(87.4)$ & 105 (63.3) & $61(36.7)$ & \multirow[t]{2}{*}{0.126} \\
\hline Yes & $24(12.6)$ & $19(79.2)$ & $5(20.8)$ & \\
\hline \multicolumn{5}{|l|}{ Schooling ${ }^{\star \star *}$} \\
\hline Suitable & $18(9.5)$ & $16(88.9)$ & $2(11.1)$ & \multirow[t]{2}{*}{0.027} \\
\hline Inappropriate & $172(90.5)$ & $108(62.8)$ & $64(37.2)$ & \\
\hline \multicolumn{5}{|l|}{ Income } \\
\hline Up to 2 Min. Wages & $127(66.8)$ & $82(64.6)$ & $45(35.4)$ & \multirow[t]{5}{*}{0.111} \\
\hline 2-4 Min. Wages & $22(11.6)$ & $11(50)$ & $11(50)$ & \\
\hline 4-10 Min. Wages & $1(0.5)$ & 0 & $1(100)$ & \\
\hline > 10 Min. Wages & $2(1.0)$ & $1(50$ & $1(50)$ & \\
\hline \multirow[t]{2}{*}{ Do not know } & $38(20)$ & $30(78.9)$ & $8(21.1)$ & \\
\hline & $\begin{array}{l}\text { Mean } \\
(\mathrm{SD})\end{array}$ & $\begin{array}{l}\text { Mean } \\
(\mathrm{SD})\end{array}$ & $\begin{array}{l}\text { Mean } \\
(\mathrm{SD})\end{array}$ & $p^{*}$ \\
\hline Age (in years) & $\begin{array}{l}14.1 \\
( \pm 2.80)\end{array}$ & $\begin{array}{l}14.50 \\
( \pm 3.01)\end{array}$ & $\begin{array}{l}13.71 \\
( \pm 2.39)\end{array}$ & 0.013 \\
\hline
\end{tabular}

chi-square test in the comparison between vaccinated and non-vaccinated.* Adoescents in the age group for HPV vaccination recommended by the Health Immu nization Program.. *** School age according to guidelines at the Brazilian Ministry of Education. SD - Standard Deviation 
Table 1 also shows that $53(54.1 \%)$ of the female adolescents reported having been vaccinated, and 62 (53.9\%) of the adolescents interviewed in the vaccination target group reported not having been vaccinated $(p<0.001)$. There was no statistical relevance among the vaccinated ones regarding the marital status, employment status, number of children, schooling, and income. The group of unvaccinated adolescents included $79(85.9 \%)$ males, and $62(82.7 \%)$ were outside the age range of free vaccination $(p<0.001)$. The vaccinated group had a lower mean age (13.71 years old \pm 2.39$)$ than the unvaccinated (14.50 years old \pm 3.01 ) adolescents $(\mathrm{p}=0.013)$.

Table 2 shows the proportion of correct answers (knowledge) among adolescents interviewed. Of a total of 190 respondents, $150(78.9 \%)$ recognized HPV as a virus; 121 (63.7\%) described HPV as a cause of cervical cancer; 148 (77.9\%) knew that the HPV vaccine is part of the immunization program for female adolescents; 115 (60.5\%) knew someone who had already received a vaccine.

TABLE 2. COMPARISON OF CORRECT ANSWERS ON HPV KNOWLEDGE AND ITS VACCINE AND ACCEPTABILITY AMONG ADOLESCENTS VACCINATED AND UNVACCINATED IN THE WESTERN AMAZON, 2017.

\begin{tabular}{|c|c|c|c|c|c|}
\hline \multirow[t]{2}{*}{ Question } & \multirow{2}{*}{$\begin{array}{l}\text { Total } \\
\text { population } \\
\mathrm{n}(\%)\end{array}$} & \multicolumn{2}{|l|}{ Vaccinated } & \multirow{2}{*}{$\begin{array}{l}\text { Gross model } \\
\text { RP (Cl95\%) }\end{array}$} & \multirow[b]{2}{*}{$\mathrm{p}$} \\
\hline & & $\begin{array}{l}\text { Not } \\
n(\%)\end{array}$ & $\begin{array}{l}\text { Yes } \\
\mathrm{n}(\%)\end{array}$ & & \\
\hline Do you know what HPV is? & $79(41.6)$ & $50(63.3)$ & $29(36.7)$ & 1.10 (0.74 to 1.63$)$ & 0.630 \\
\hline Is HPV a virus? & $150(78.9)$ & $103(68.7)$ & $47(31.3)$ & 0.66 (0.44 to 0.99) & 0.043 \\
\hline Is HPV a sexually transmitted disease? & $130(68.4)$ & $88(67.7)$ & $42(32.3)$ & $0.81(0.54$ to 1.20$)$ & 0.293 \\
\hline Can HPV cause cervical cancer? & $121(63.7)$ & $70(57.9)$ & $51(42.1)$ & 1.94 (1.18 to 3.18) & 0.009 \\
\hline Can HPV cause changes in the Papanicolaou? & $93(49)$ & $65(699)$ & $28(30.1)$ & $0.77(0.52$ to 1.14$)$ & 0.195 \\
\hline Is cervical cancer a major cause of cancer in women? & $149(78.4)$ & $93(62.4)$ & $56(37.6)$ & 1.54 (0.86 to 2.75$)$ & 0.143 \\
\hline Can smoking increase the risk of cervical cancer? & $101(53.2)$ & $70(69.3)$ & $31(30.7)$ & $0.78(0.53$ to 1.15$)$ & 0.215 \\
\hline Does the HPV vaccine prevent cervical cancer? & $141(74.2)$ & $93(66)$ & $48(34)$ & 0.93 (0.60 to 1.43$)$ & 0.731 \\
\hline Should the HPV vaccine be given before the first sexual intercourse? & $116(61)$ & $74(63.8)$ & $42(36.2)$ & $1.12(0.74$ to 1.68$)$ & 0.598 \\
\hline Can the HPV vaccine be given to people who have had sex? & $86(45.3)$ & $57(66.3)$ & $29(33.7)$ & 0.95 (0.64 to 1.40$)$ & 0.790 \\
\hline Can the HPV vaccine be harmful to health? & $121(63.7)$ & $75(62)$ & $46(38)$ & 1.31 (0.85 to 2.03$)$ & 0.222 \\
\hline Can the HPV vaccine cause HPV infection? & $75(39.5)$ & $51(68)$ & $24(32)$ & 0.88 (0.58 to 1.32$)$ & 0.527 \\
\hline Is the HPV vaccine provided by the Government? & $155(81.6)$ & $101(65.2)$ & $54(34.8)$ & $1.02(0.61$ to 1.69$)$ & 0.951 \\
\hline Is the HPV vaccine part of the girls' immunization record? & $148(77.9)$ & $88(59.5)$ & $60(40.5)$ & 2.84 (1.32 to 6.12$)$ & 0.008 \\
\hline Are 3 doses required for complete vaccination? & $109(57.4)$ & $66(60.6)$ & $43(39.4)$ & 1.39 (0.91 to 2.11) & 0.123 \\
\hline Does the HPV vaccine lessen the chance of having genital warts? & $89(46.8)$ & $61(68.5)$ & $28(31.5)$ & 0.84 (0.56 to 1.24$)$ & 0.378 \\
\hline Does the HPV vaccine decrease the chance of having Pap test changes? & $85(44.7)$ & $59(69.4)$ & $26(30.6)$ & $0.80(0.54$ to 120$)$ & 0.286 \\
\hline \multicolumn{6}{|l|}{ Acceptability } \\
\hline \multicolumn{6}{|l|}{$\begin{array}{l}\text { Do you think that the HPV vaccine would stimulate the onset of } \\
\text { sexual life earlier? }\end{array}$} \\
\hline Yes & $89(46.8)$ & $64(71.9)$ & $25(28.1)$ & & \\
\hline No & $101(53.2)$ & $60(59.4)$ & $41(406)$ & 1.44 (0.96 to 2.17$)$ & 0.077 \\
\hline \multicolumn{6}{|l|}{$\begin{array}{l}\text { Do you think that after the HPV vaccine you still need to use a con- } \\
\text { dom? }\end{array}$} \\
\hline No & $32(16.8)$ & $21(65.6)$ & $11(34.4)$ & & \\
\hline Yes & $158(83.2)$ & $103(65.2)$ & $55(34.8)$ & 1.01 (0.60 to 1.71$)$ & 0.963 \\
\hline \multicolumn{6}{|c|}{$\begin{array}{l}\text { Do you think that after the HPV vaccine you still need to have the Pap } \\
\text { test? }\end{array}$} \\
\hline No & $38(20)$ & $24(63.2)$ & $14(36.8)$ & & \\
\hline Yes & $152(80)$ & $100(65.8)$ & $52(34.2)$ & 0.93 (0.58 to 1.49$)$ & 0.758 \\
\hline \multicolumn{6}{|l|}{ Do you know anyone who has already had the HPV vaccine? } \\
\hline No & $75(39.5)$ & $62(82.7)$ & $13(17.3)$ & & \\
\hline Yes & $115(60.5)$ & $62(53.9)$ & $53(46.1)$ & 2.66 (1.56 to 4.53$)$ & $<0.001$ \\
\hline \multicolumn{6}{|l|}{$\begin{array}{l}\text { Would you recommend the HPV vaccine for a child, friend or relative } \\
\text { to take? }\end{array}$} \\
\hline No & $20(10.5)$ & $16(80)$ & $4(20)$ & & \\
\hline Yes & $170(89.5)$ & $108(63.5)$ & $62(36.5)$ & $1.82(0.74$ to 4.49$)$ & 0.191 \\
\hline
\end{tabular}

*Poisson regression with robust variance 


\section{GRAPH 1}

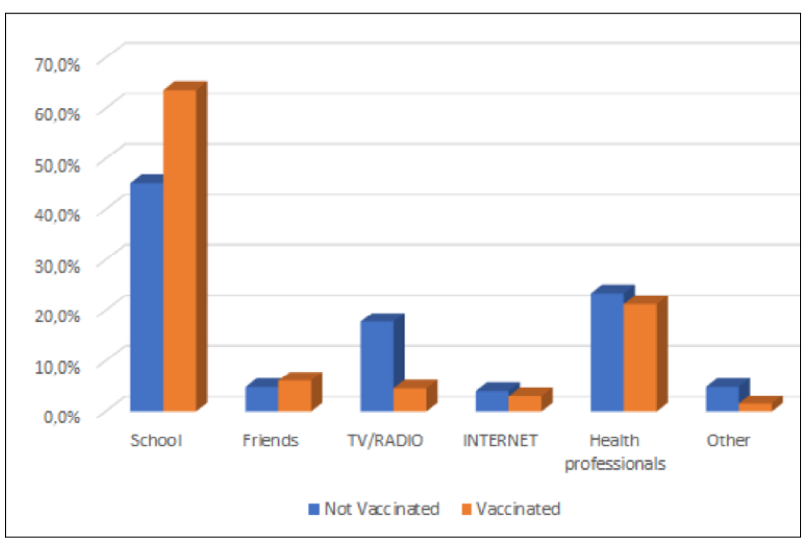

Participants who knew HPV was a causative factor in cervical cancer were 1.94 (CI 1.18 a 3.18; $\mathrm{p}=0.009$ ) times more likely to have been vaccinated than those who did not. Moreover, participants who knew that the HPV vaccine is part of the immunization program for female adolescents were 2.84 (CI $1.32-6.12$; $\mathrm{p}=0.008$ ) times more likely to have been vaccinated than those who did not.

Graph 1 shows the main sources of information for adolescents in Acre. Schools (51,6\%) and health professionals $(22,6 \%)$ are the main sources of information on HPV vaccination in both populations.

\section{DISCUSSION}

The assessment of acceptability and knowledge about HPV and its vaccine among adolescents is an important outcome for the health of this population and public health since they are in a period of experimentation and initiation of sexual activity, thus vulnerable to Sexually Transmitted Infections (STI) ${ }^{5,10,11}$. In the State of Acre, vaccination rates for HPV have not yet reached the goals of the National Immunization Program or the goals expected by $\mathrm{WHO}^{2,3}$.

The results show that non-vaccinated adolescents present knowledge gaps compared to those vaccinated. In addition, they reported barriers to vaccine acceptability, such as the belief that this stimulates the onset of sexual activity.

The prevalence of high-risk HPV cervical cancer in the territory of Acre is $71 \%$, which reinforces the importance of identifying knowledge gaps and acceptance barriers for the HPV vaccine ${ }^{12}$. In our study, we describe the knowledge of adolescents from Acre about HPV being a virus and its relation to cervical cancer. A convergent study ${ }^{13}$ conducted with adolescents in Santa Catarina, Brasil, with the fourth-highest income ${ }^{14}$, showed the respondents presented basic notions about the subject.

Gualano et al. ${ }^{15}$ corroborate that adolescents vaccinated for HPV have a better level of knowledge about the virus and its relation to cancer than those not vaccinated. Studies have shown divergent results with adolescents in Greece ${ }^{16}$ and the US ${ }^{17}$, pointing out that the HPV vaccine is present in the vaccination program for adolescents in Greece; however, in the US, the vaccine for HPV is not provided without cost by the Government.

Knowledge gaps among the unvaccinated include: HPV being a virus and not being related to cervical cancer; no knowledge about the HPV vaccine being part of the girls' official immunization calendar, and not knowing individuals who have already been vaccinated for HPV. Studies conducted in England, where the vaccine is available for adolescents aged 12 to 18 years, corroborate our findings and state that vaccinated girls were more likely to have heard of HPV than unvaccinated $^{\text {ones18. }}$.

Respondents showed they did not know that the HPV vaccine can be applied to those who have had sex. It is important to emphasize that vaccination will be more effective if applied early, especially before the first sexual contact. However, even if they are already sexually active, they will benefit because they will be protected against other types of HPV contained in the vaccine. And the vaccinated population will present an effective and timely immune response ${ }^{2}$.

In addition, adolescents may be reinfected with different types of HPV viruses during their lifetime if there is no double protection (association with a condom). In this study, the adolescents demonstrated knowledge about preventive measures, the use of condoms, and cervical cancer screening exams after vaccination ${ }^{2}$. Chiang et al. ${ }^{19}$ found in their results that adolescents of both sexes are interested in being vaccinated or recommending the vaccine to relatives.

The main sources of information for HPV vaccination among adolescents in Acre were schools and health professionals. It is worth mentioning the importance of the school environment in the sexual, reproductive, and preventive education of adolescents. Investments in sex education and the development of educational campaigns on Papanicolaou with an appropriate approach and appropriate language applied in the prevention of cervical cancer are necessary ${ }^{15,20}$.

Our results reinforce the importance of intersectionality between health and education, with 
FIGURE 1.

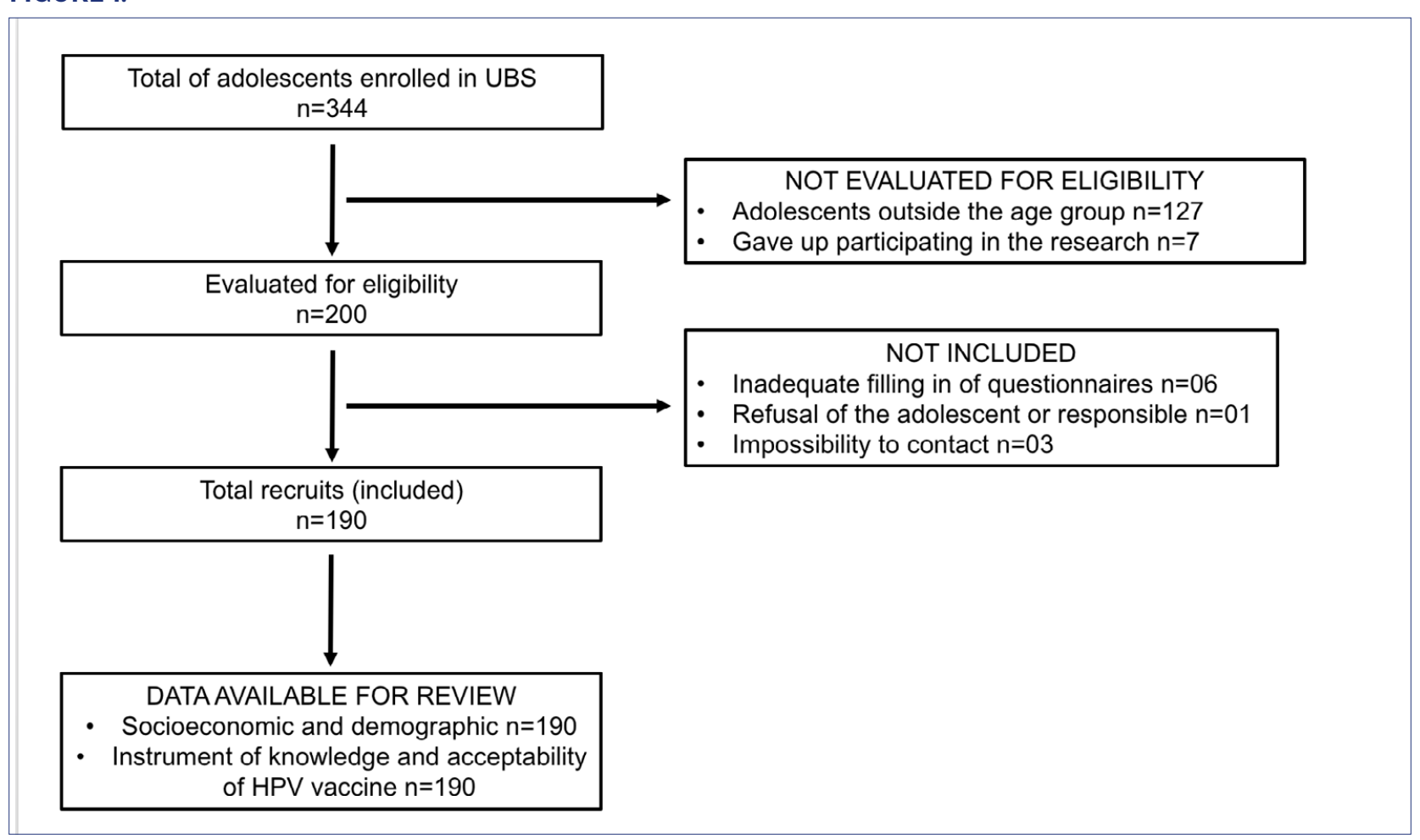

joint informative campaigns expanded and making it possible to demystify the concepts for better knowledge and acceptability of the HPV vaccine. The first HPV vaccination campaign in Brasil took place in partnership with public and private schools ${ }^{21}$, which may have contributed to the school environment being the source of information most cited among adolescents.

The literature shows that health professionals advise on Pap smears and cervical cancer, but have gaps in knowledge about the effects of HPV on adolescent health and the benefits of the vaccine for men ${ }^{5,22,23}$. In the study by Lorenzi et al. ${ }^{24}$, they analyzed whether age is a barrier against the acceptability of cervicovaginal self-sampling in screening for cervical cancer, and they concluded that younger women indicated more fear and discomfort in self-sampling, which points to the need for attraction strategies that are more appealing to the younger generations. Moreover, the self-collection method is well-accepted and may, therefore, encourage greater participation in cervical cancer screening programs ${ }^{25}$.

Misconceptions about the HPV vaccine are barriers to the vaccination of adolescents, especially in the age group that depends on the parents or guardians to get vaccinated. The stimulation of early sexual life should be demystified among the population, and counseling on the subject should be encouraged by health professionals ${ }^{5,6,26}$.

Papillomavirus infection is a viral STI that most affects the sexually active world population. Knowledge about HPV strengthens the prevention of STIs and the long-term incidence of new cases of cervical cancer ${ }^{2}$.

In a cross-sectional study, a descriptive approach can be considered a limitation, as well as the impossibility of measuring causal relationships between knowledge and acceptability barriers in the interviewed population. Still, there is a bias in the variable of knowledge and perception about the HPV vaccine, since the interviewees were ill with easy access to health, not expressing the reality of other adolescents.

The novelty of the study is considering the perceptions of adolescents of both sexes about HPV, its clinical repercussions, and its vaccine in a territory of low adherence to vaccination and high rates of cervical cancer. Adolescents showed good acceptance and are recommended for HPV vaccination.

Thus, health team counseling for family members and adolescents about the HPV vaccine is necessary, as well as intersectoral health promotion actions to resolve doubts and myths about the vaccine and raise awareness among the population (adolescents and guardians) on the prevention of HPV to extend the recommended vaccination coverage. 


\section{CONCLUSION}

Unvaccinated adolescents have gaps in knowledge about HPV and its vaccine compared to those vaccinated. Moreover, unvaccinated adolescents reported barriers to vaccination, such as the belief that this stimulates the onset of sexual activity. School and friends are sources of exchange of knowledge and information among vaccinated adolescents.

Thus, it is noted that training is necessary for health teams, families, and adolescents in order to increase the population's knowledge about HPV, its clinical repercussions, and its vaccine, as well as to cover the WHO recommended percentage of vaccine coverage.

Implications and Contribution: To address the perceptions of adolescents of both sexes about HPV, its clinical repercussions, and its vaccine in a territory of low adherence to vaccination and high rates of cervical cancer. Adolescents showed good acceptance and are recommended for HPV vaccination.

\section{RESUMO}

OBJETIVO: Analisar o nível de conhecimento e aceitabilidade da vacina contra o HPV entre adolescentes vacinados e não vacinados na Amazônia Ocidental.

MÉTODOS: Estudo transversal com adolescentes de 10 a 19 anos. O instrumento usado para coletar dados contém informações demográficas e socioeconômicas e 27 perguntas que avaliam o conhecimento e a aceitabilidade da vacina contra o HPV. Para comparar a prevalência de adolescentes vacinados com as respostas corretas para perguntas sobre conhecimento, aceitabilidade e vacinação contra o HPV, o modelo de regressão de Poisson de variância robusta foi utilizado no software Stata 13.0. Resultados: Participaram do estudo 190 adolescentes, 60,5\% ( $n=115)$ na faixa etária de vacinação recomendada pelo governo brasileiro; dentre eles, 53,9\% ( $n=62)$ relataram não ter sido vacinados $(p<0,001)$. A proporção de resultados corretos entre os adolescentes foi de 78,9\% ( $n=150)$, que reconheceram o HPV como vírus; 63,7\% (n=121) relataram o HPV como causa de câncer do colo do útero. Os participantes que sabem que o HPV é um fator causal no câncer do colo do útero têm 1,94 (IC 1,18-3,18; $p=0,009$ ) vez mais chances de terem sido vacinados do que aqueles que não sabem. Entre os entrevistados, as principais fontes de conhecimento sobre a vacina foram escolas (51,6\%) e profissionais de saúde (22,6\%)

CONCLUSÃO: Adolescentes não vacinados apresentam lacunas de conhecimento sobre o HPV e sua vacina quando comparados aos vacinados. Nossos resultados enfatizam a necessidade de campanhas eficazes para fornecer informações adequadas sobre o HPV $e$ sua vacina a adolescentes, pais e profissionais de saúde.

PALAVRAS-CHAVE: Percepção. Vacinas. Papillomaviridae. Adolescente.

\section{REFERENCES}

1. Brasil. Ministério da Saúde, Secretaria de Vigilância em Saúde. Informe Técnico da ampliação das vacinas papilomavírus humano 6, 11, 16 e 18 (recombinante) - vacina HPV quadrivalente e meningocócica C (conjugada). Brasília: Ministério da Saúde; 2018.

2. World Health Organization. Human papillomavirus vaccines: WHO position paper, May 2017 - Recommendations. Vaccine. 2017;35(43):5753-5.

3. Datasus. Sistema de Informações do Programa Nacional de Imunizações (SI-PNI) [web site] 2018 [cited 2018 Dec 7]. Available from: http://pni. datasus.gov.br/

4. Zardo GP, Farah FP, Mendes FG, Franco CAGS, Molina GVM, Melo GN, et al. Vacina como agente de imunização contra o HPV. Ciênc Saúde Coletiva. 2014;19(9):3799-808.

5. Sousa PDL, Takiuti AD, Baracat EC, Sorpreso ICE, Abreu LC. Knowledge and acceptance of HPV vaccine among adolescents, parents and health professionals: construct development for collection and database composition. | Hum Growth Dev. 2018;28(1):58-68.

6. Sorpreso ICE, Kelly PJ. HPV vaccine: knowledge and acceptance to ensure effectiveness. | Hum Growth Dev. 2018;28(1):5-8.

7. von Elm E, Altman DG, Egger M, Pocock S|, Gøtzsche PC, Vandenbroucke JP; STROBE Initiative. The Strengthening the Reporting of Observational Studies in Epidemiology (STROBE) statement: guidelines for reporting observational studies. Int | Surg. 2014;12(12):1495-9.

8. World Health Organization. The health of youth. Document A42/Technical Discussions/2. Geneva: World Health Organization; 1989.

9. Cronbach LJ. Coefficient alpha and the internal structure of tests. Psychometrika. 1951;16:297-334.
10. Zimet GD, Liddon N, Rosenthal SL, Lazcano-Ponce E, Allen B. Chapter 24: Psychosocial aspects of vaccine acceptability. Vaccine. 2006;24(Suppl 3):S3/201-9.

11. Silva ATM, Sousa GD, Menezes CL, Ferreira Filho ES, Pinheiro WS, Soares únior JM, et al. Vulnerability in adolescence: a case report of attempted abortion and sexual violence. | Hum Growth Dev. 2017;27(1):117-23.

12. Associação Hospitalar Moinhos de Vento. Estudo epidemiológico sobre a prevalência nacional de infecção pelo HPV (POP-Brasil): resultados preliminares. Porto Alegre: Associação Hospitalar Moinhos de Vento; 2017. [cited 2020 lan 6]. Available from: http://www.iepmoinhos.com.br/pesquisa/ downloads/LIVRO-POP_Brasil___Resultados_Preliminares.pdf

13. Instituto Brasileiro de Geografia e Estatística. Diretoria de Pesquisas, Coordenação de Trabalho e Rendimento. Pesquisa Nacional por Amostra de Domicílios Contínua - PNAD Contínua - 2017. [cited 2020 lan 6]. Available from: ftp://ftp.ibge.gov.br/Trabalho_e_Rendimento/Pesquisa_Nacional_por_Amostra_de_Domicilios_continua/Renda_domiciliar_per_capita/ Renda_domiciliar_per_capita_2017.pdf

14. Badotti FSS, Almeida RB, Kreuger MRO. Nível de conhecimento dos adolescentes das escolas do município de Itajaí-SC sobre o vírus papiloma humano (HPV). Rev Adol Confl. 2018;17:2-8

15. Gualano MR, Stillo M, Mussa MV, Zotti CM. Cross sectional study investigating the differences in knowledge and behaviors about HPV between vaccinated and non-vaccinated girls. J Prev Med Hyg. 2016;57(3):E121-7.

16. Anagnostou PA, Aletras VH, Niakas DA. Human papillomavirus knowledge and vaccine acceptability among adolescents in a Greek region. Public Health. 2017;152:145-52. 
17. Dillard JP, Spear ME. Knowledge of human papillomavirus and perceived barriers to vaccination in a sample of US female college students. J Am Coll Health. 2010;59(3):186-90.

18. Bowyer HL, Marlow LA, Hibbitts S, Pollock KG, Waller J. Knowledge and awareness of HPV and the HPV vaccine among young women in the first routinely vaccinated cohort in England. Vaccine. 2013;31(7):1051-6.

19. Chiang VC, Wong HT, Yeung PC, Choi YK, Fok MS, Mak OI, et al. Attitude, acceptability and knowledge of HPV vaccination among local university students in Hong Kong. Int J Environ Res Public Health. 2016;13(5). Pii: E486.

20. Cirino FMSB, Nichiata LYI, Borges ALV. Conhecimento, atitude e práticas na prevenção do câncer de colo uterino e HPV em adolescentes. Esc Anna Nery. 2010;14(1):126-34.

21. Brasil. Ministério da Saúde. Secretaria de Vigilância em saúde. Departamento de vigilância de doenças transmissíveis. Coordenação-Geral do programa nacional de imunizações. Informe técnico sobre a vacina contra o papilomavírus humano (HPV) na atenção básica. Brasília: Ministério da Saúde; 2014.
22. Pereira JEG, Gomes JM, Costa AS, Figueiredo FWDS, Adami F, Santos EFS, et al. Knowledge and acceptability of the human papillomavirus vaccine among health professionals in Acre state, western Amazon. Clinics (Sao Paulo). 2019;74:e1166.

23. Holman DM, Benard V, Roland KB, Watson M, Liddon N, Stokley S. Barriers to human papillomavirus vaccination among US adolescents: a systematic review of the literature. |AMA Pediatr. 2014;168(1):76-82.

24. Lorenzi NPC, Termini L, Longatto Filho A, Tacla M, Aguiar LM, Beldi MC, et al. Age-related acceptability of vaginal self-sampling in cervical cancer screening at two university hospitals: a pilot cross-sectional study. BMC Public Health. 2019;19(1):963.

25. Braz NS, Lorenzi NP, Sorpreso IC, Aguiar LM, Baracat EC, Soares-júnior JM. The acceptability of vaginal smear self-collection for screening for cervical cancer: a systematic review. Clinics (Sao Paulo). 2017,72(3):183-7.

26. Markowitz L, Unger ER. Human papillomavirus. In: Hamborsky J, Kroger A, Wolfe S, eds. Epidemiology and prevention of vaccine-preventable diseases. $13^{\text {th }}$ ed. Washington: Centers for Disease Control and Prevention; Public Health Foundation; 2015. 